\title{
非定常非ダルシー自由水面流れの一数值解法 \\ A NUMERICAL METHOD FOR ANALYZING NON-STEADY NON-DARCY FLOW WITH A FREE SURFACE
}

\author{
山上拓 男* - 末 原 光 喜** \\ By Takuo YAMAGAMI and Kouki SUEHARA
}

\section{1. まえがき}

粗粒材よりなる土構造物内の浸透は多くの場合非ダル シー流れとなることが知られている.こうした非ダルシ 一浸透問題のなかで，定常流れについてはすでに簡便な 数值解析法を提案している ${ }^{1)}$. 本論文は, 先に提案した 解析法をさらに発展させて, 非定常非ダルシー自由水面 問題の FEM による簡易解析法を提案するものである. その概要は先と同様線形計算の繰返しで非線形流れを近 似することであり，主として外水位低下時のロックフィ ルダムを想定している.

これまでダルシー流れの非定常浸透問題の数值解析は 実に多くの研究成果が公表されてきた．しかし本論文で 対象とする非ダルシー流れとしての非定常問題を取り扱 った研究は非常に少なく，わずかに McCorquodale ${ }^{2)}$, McCorquodale and Nasser ${ }^{3)}$, Huyakorn ${ }^{4)} ら の$ 論文が みられるにすぎない.この分野の論文が数少ない理由の 一つは理論構成が複雑で定式化が困難なところに求めら れよう.しかしより大きい理由として, 多孔体の浸透現 象はダルシー則で十分記述し得るとする風潮があるよう に思われる. 確かに, 浸透問題の多くはダルシー則に支 配されるとしてなんら支障はないけれども, 一方におい て, 粗粒材の透水試験を行うと, 必ずといってよいほど に測定結果にばらつきが経験されることも事実である.

こうしたばらつきがもろもろの測定誤差に起因するので あれば論外であるが, 本来の意味の非線形性であれば, それらの平均值を用いてダルシー流れとして解くことよ りも,むしろ積極的に非線形性を認めた解析法へ進むべ きと考える.ただし，いたずらに複雑な定式化や演算時 間を要するものであれば実用上の意義は少ないといわね ばならない.

* 正会員 工博 徳島大学助教授 工学部建設工学科

** 正会員 工修 大阪府岬町役場水道事業課
本研究では, 上述の観点から新たに提案する簡易解析 法の詳細を論述し, 加えてこのよらな解法の有用性を検 証すべく，模型実験結果を交えた考察を試みる.

\section{2. 解析法の詳細}

本論文で取り扱ら非定常非ダルシー自由水面流れの特 徵は，運動方程式が非線形であることと，外水位変動に 伴って自由水面が逐次移動している点である.このうち 前者の運動方程式の非線形性の考慮は定常解析の手法 ${ }^{1)}$ を，また後者の自由水面追跡法はダルシー流れとしての それら゙を応用することができる．このため，はじめに本 文で必要とする範囲内に限定して，これら既往の手法と それに伴う基本的関係式を要約し，ついでアイソパラメ トリック要素に基づく本解析法を詳しく論じることにす る.

\section{（1）定常非ダルシー自由水面流れ1)}

前論文で提案した自由水面を有する定常非ダルシー浸 透問題の解析法すなわち反復法の要点を 図一1 に示し た. 罒において，I，v はそれぞれ動水勾配と流速であっ て，I=F(v) で非線形運動方程式を一般表示したもの である，まず，この解法がダルシー流れの反復を基底と しているため, 各反復段階に応じた透水係数を評価しつ

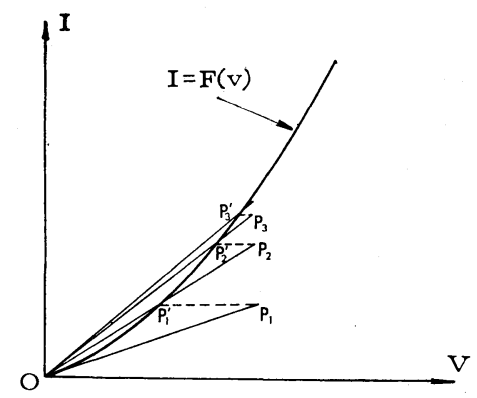

図一1 反復法の説明 
つ計算せねばならない。これには図一1において，原点 から運動方程式への割線の勾配の逆数を当てればよかっ た. このように定義された透水係数は真の透水係数では ないので, 前論文では疑似透水係数と名付けておいた. しかしここでは改めて反復法の疑似透水係数を, 非線形 力学の割線弾性係数にちなんで割線透水係数とよぶこと にする.このとき定常問題としての自由水面決定法の概 要は以下のようである.

まず最初, 適当に仮定された自由水面のもとに, 解析 領域全体の要素が一様に初期割線透水俰数を有するもの として, ダルシー流れの解法に従って, この場合の正し い（初期割線透水係数に対応した）自由水面を決定す る. しかしその結果の $(I, v)$ 点は図の $P_{1}$ 点で表わさ れるように，運動方程式からかなり偏倚したところに落 ち着くと予想される.このとき, 偏倚量 $\overline{P_{1} P_{1}{ }^{\prime}}$ があら かじめ規定された許容值より大であれば，引き続き原点 と $P_{1}{ }^{\prime}$ 点を結ぶ直線の勾配の逆数を 新たな 割線透水係 数として,これら割線透水係数に応じた自由水面が定ま るまで線形計算を絽り返す。このような過程を継続し， 第 $i$ 反復段階終了時の 偏倚量 $\overline{P_{i} P_{i}{ }^{\prime}}$ がすべての要素で 許容值内に収まれば, 運動方程式に関して解は収束した ものと考える. 同時に, そのとき求められている自由水 面位置が求めるべき非ダルシー流れとしての自由水面で あると見なす。

\section{（2）基礎式の要約}

上述したように，この解析法は定常，非定常を問わず ダルシー流れの解析の反復で非ダルシー流れを近似せん とするものである．したがって，流れを支配する基礎微 分方程式も各反復段階ごとにダルシー流れとしてのそれ が適用される.すなわち，間隚水・多孔体をともに非圧 縮性と仮定するとき, 2 次元状態で,

$$
\frac{\partial}{\partial x}\left(k_{x} \frac{\partial H}{\partial x}\right)+\frac{\partial}{\partial y}\left(k_{y} \frac{\partial H}{\partial y}\right)=0
$$

である.ここに, $H$ は全水頭, $k_{x}, k_{y}$ は $x, y$ 方向の 透水係数であるが，本論文では等方性場を対象としてい るため $k_{x}=k_{y}$ である.ただし，異方性場へ拡張するこ とはなんら困難な問題ではない。

上式を変分法もしくは重み付き残差法 (Galerkin 法) のもとに有限要素で離散化すれば, アイソパラメトリッ ク要素の場合, 要素の浸透性行列 $[h]^{e}$ が次式のように 導かれる.

$$
\begin{aligned}
& {[h]^{e}=\int_{-1}^{1} \int_{-1}^{1}[B J]^{T}[R][B J] \operatorname{det}[J] d \xi d \eta} \\
& {[B J]=[J]^{-1}[B]} \\
& {[R]=\left[\begin{array}{cc}
k_{x} & 0 \\
0 & k_{y}
\end{array}\right]}
\end{aligned}
$$

ただし， $[J]^{-1}$ はヤコビアンマトリックス $[J]$ の逆マ トリックス， $[B]$ は要素のタイプを 1 次要素としてそ の形状関数を $\left[N_{1} N_{2} N_{3} N_{4}\right]$ とするとき，

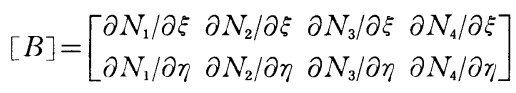

で定義され，局所（自然）座標系 $(\xi, \eta)$ の関数となる.

\section{（3）非定常非ダルシー自由水面流れ}

外水位変動時の自由水面追跡法はダルシー 流れの場 合 ${ }^{5)}$ と本質的に同じである.すなわち，図一2 において 時刻 $t$ の自由水面 $E_{t} C_{t}$ が既知であるとして, 時刻 $t+$ $\Delta t$ の新たな自由水面位置 $E_{t+\Delta t} C_{t+\Delta t}$ を定めるものと する.このとき，解析領域は時刻 $t$ のものを，また境界 条件としての外水位は時刻 $t+\Delta t$ の状態を用いて定常解 析を行う.その結果, 自由水面上の間隚水の真の流速に タイムステップ $\Delta t$ を乗じた值が $\Delta t$ 間の自由水面の移 動量となる.この操作を初期状態から所定の時刻まで繰 り返し継続するのであるが，運動方程式が非線形である

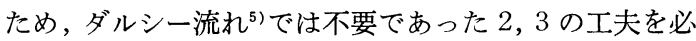
要と寸る. その際, 前述 (1) の定常自由水面問題に対 する運動方程式の近似方法が生かされることになる。こ の間の状況を 図一2，3 の模式図で説明しょう.

図一2 で任意要素 $e$ に注目し, この要素の時刻 $t$ に おける合速度を $v_{t}{ }^{e}$ ，合動水勾配を $I_{t}{ }^{e}$ とする。 そして これら $\left(I_{t}{ }^{e}, v_{t}{ }^{e}\right)$ が 図一 3 に示寸運動方程式上の $P$ 点

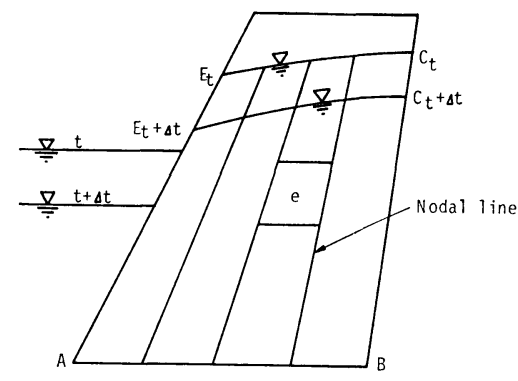

図一2 自由水面追跡法

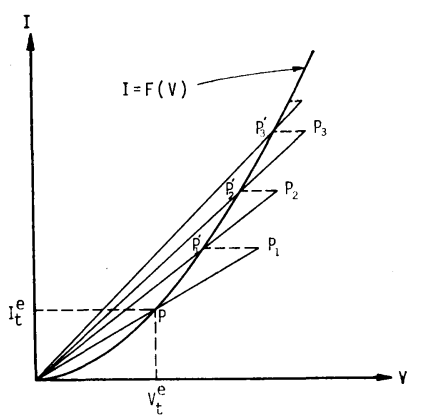

图-3 運動方程式上の反復過程の説明 
で与えられるものとする．まず，次式

$$
k_{t}{ }^{e}=v_{t}^{e} / I_{t}{ }^{e}
$$

でこの要素の割線透水倸数を評価し第 1 回目の線形計算 を行うと，その結果は 図一3の $P_{1}$ 点で表わされるよ らな運動方程式からかなり偏倚したところに落ち着くこ とが予想される。このとき偏倚量 $\overline{P_{1} P_{1}{ }^{\prime}}$ があらかじめ 規定された許容值より大であれば，引き続き原点と $P_{1}{ }^{\prime}$ 点を結ぶ 直線の勾配の 逆数を新たな 割線透水係数とし て，同じ解析領域および境界条件のもとに線形計算を再 度繰り返す。こうした手順を継続し，すべての要素で偏 倚量 $\overline{P_{i} P_{i}{ }^{\prime}}$ が許容值内に収まれば 運動方程式に関して 解は収束したものとして，ただちに自由水面上の流速か ら $\Delta t$ 間の移動量を求め, 時刻 $t+\Delta t$ の自由水面 $E_{t+\Delta t}$ $C_{t+\Delta t}$ が決定される。

ここで上述した操作に付随して 2 つの注意事項を指摘 しておかねばならない，第1は，式（6）で与えられる 各要素の割線透水俰数を要素内のいかなる点で評価す心゙ きかといった問題である． 3 節点三角形要素の場合，動 水勾配が要素内で一定となるためこのような選択の余地 は残らないのであるが，本研究で一貫して利用している アイソパラメトリック要素となると事情は多少異なり, その次数にかかわりなく要素内で動水勾配が変化する。 したがって式（6）に基ゔく割線透水係数もまた場所の 関数となるのである.この問題に関する最も論理的な対 処の仕方は, 要素の浸透性行列を Gauss 求積法で評価 する際，並行して割線透水係数も Gauss point におけ る值を用いることである.つまり式（2）を数值積分す るとき， $[R]$ も局所座標 $(\xi, \eta)$ の関数と見なして各 Gauss point に応じた流速と動水勾配より式（6）で割 線透水係数を定め，この值を式（4）に代入するのであ る.

割線透水係数が場所的に変化する場合のいま 1 つの対 処の仕方は, 数值積分点の数にかかわりなく要素中心の 值で代表させることである．この方法は精度上多少のあ いまいさを残すとしても，何よりも簡便なところが大き い利点である．そして非ダルシー流れに関する著者らの 解析例は，先の定常流れの論文も含めすべてこの方法に よっている．著者らは，はじめに述べた論理的な割線透 水係数の評価法を試みた経験はないけれども，仮にその ような手法を用いたとすれば，少なくともこの論文で呈 示する計算結果より精度の高い解が得られるであろう.

次に，自由水面上の流速を求めることと関連して，上 述した割線透水係数の場所的変化がやはり問題となる. すなわち，自由水面上の流速はこの位置における動水勾 配と割線透水係数の積で与えられるため, 厳密には要素 内で透水性が変化していることを考慮せね攼ならない， しかしこの研究では割線透水係数については簡単に要素

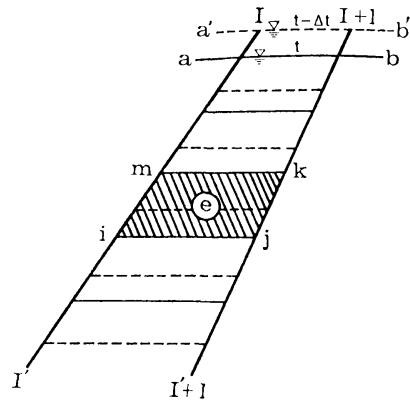

\section{図-4 自由水面の移動に伴う要素網の再分割}

中心の值で代用していることを前もって記しておく．

第 2 の注意事項は，飽和領域のみを対象とした解法に 本来的に備わった難点である. この様子を図一4に示し

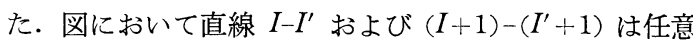
の相隣る 2 本の nodal line を表わす. また $\overparen{a^{\prime} b^{\prime}}$ は時 刻 $t-\Delta t$ の 自由水面である. そしてこのときの 2 本の nodal line 間にある要素網が破線 で示されている。 方, $\widehat{a b}$ はこのような時刻 $t-\Delta t$ の自由水面で規定され る解析領域, および時刻 $t$ の境界条件としての外水位の もとに，運動方程式が満たされるまで繰り返し計算を行 ったのち節点 $I, I+1$ の真の流速から決定された時刻 $t$ の自由水面を示している. この際, 自由水面が $\overparen{a^{\prime} b^{\prime}}$ か ら $a b$ に移動したことに伴い, 可動領域の要素網が自動 的に再分割されるため時刻 $t-\Delta t$ の状態とは異なった要 素分割状況が出現する．これが図中実線で表わされた要 素網である.いま時刻 $t$ の自由水面状態からさらにその 次の時刻 $t+\Delta t$ の自由水面を定めるものとし, 任意要素 $e$ に注目する. このとき，第 1 回目の線形計算に要する 割線透水係数を式（6）で評価せねばならないむむろん 上述したように式 (6) の $v_{t}{ }^{e}, I_{t}{ }^{e}$ は要素 $e$ の中心で計 算された值を用いる．しかるに要素網が再分割された直 後には, 要素 $e$ の 4 節点 $i, j, k, m$ の水頭值が未知で あるためこのような要素中心の動水勾配や流速を求める ことはできない，こうした難点が生じるのは，各タイム ステップごとに自由水面位置および要素分割の修正を要 寸るためである. そこでこの研究では, 要素 $e$ の中心 が一歩手前の要素網すなわち時刻 $t-\Delta t$ の要素網のいず れの要素内に位置するかを調べ，その要素中心が 時刻 $t-\Delta t$ で運動方程式に関する解が収束した時点で有して いた動水勾配と流速を用いて，第 1 回目の割線透水係数 を求める方法をとっている. 第 2 回目以降の計算段階で はこのような問題点の生じないことは明らかである.

対象時間の全段階を通じて要素網の再配列を必要とし ない飽和・不飽和領域を一体とした解析法 ${ }^{6}$ の利点を, このような非ダルシー場に持ち込むならば，上述した方 策に伴ら煩雑さは回避し得る意味で, 今後の検討が望ま れる。 


\section{3. 実験の概要}

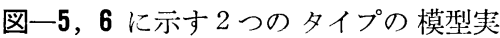
験を行った. 前者は中央コア型ロックフィ ルダムを想定したもので，コア部を不透水 性とみて上流側ロック部のモデルを図に示 す諸寸法の水槽内に設けた。ただし奥行方 向の長さは $19.7 \mathrm{~cm}$ である.この実験は 貯水池水位が初期の $45 \mathrm{~cm}$ から急激に降 下する際の堤体内各点の圧力水頭の変化を 測定することである. また後者の実験は， 上・下流側貯水池水位が同一レベルにある 均一型模型ダムにおいて, やはり片側水位 が初期の $31 \mathrm{~cm}$ から $18 \mathrm{~cm}$ まで降下する 際の圧力水頭を測定することである. 中央

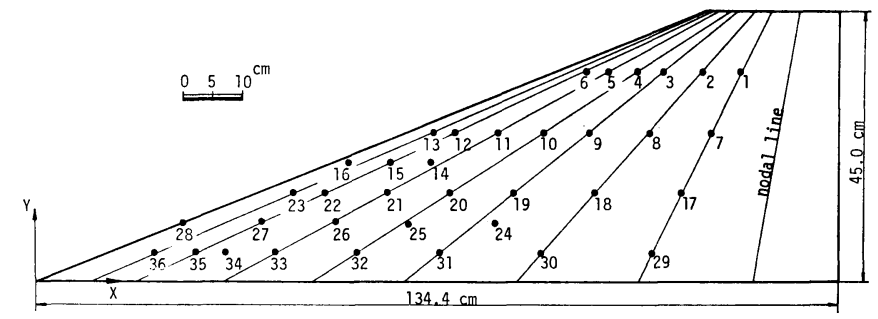

図一7 水頭測定用バルブの配圈図 (中央コア型)

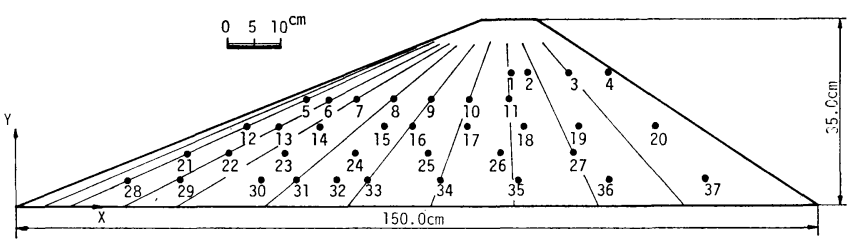

図一8 水頭測定用バルブの配囯図（均一型ダム） コア型ダムに比べ均一型ダムの外水位変動範囲が小さい のは, 後者の場合, 上・下流側水位差を大きく取り過ぎ ると浸出点近傍で局部破壊が生じる危険性を䀣念したこ とによる. 堤体材料はいずれも徳島県鳴門市産の砕石で あって, $5 \mathrm{~mm}$ ふるいを通過し， $2 \mathrm{~mm}$ ふるいに残留す るものを用いた. 試料の外観は写真一3に示してある. 水槽内に水洗いしたロック材を各層厚約 $5 \mathrm{~cm}$ として中 央コア型ダムは 9 層に, また均一型ダムは 7 層に分けて 敷設し, 各層について重さ $2 \mathrm{~kg}(19.6 \mathrm{~N})$, 底面積 100 $\mathrm{cm}^{2}(10 \mathrm{~cm} \times 10 \mathrm{~cm})$ のランマーにより $4 \mathrm{~cm}$ の自由落 下で 1 か所当たり 20 回まんべんなく突き固めた.この ようにしてできたダムの平均的な有効間隚率は, 中央コ ア型ダムに対し $\beta=0.364$, また均一型ダムは $\beta=0.342$ である，ただし，有効間隚率はダム完成後，天端まで水

を張り，貯水側水位を低下させたとき排水可能な水量か ら決定した. なお, ダム内各点の密度の不均一性に起因 して $\beta$ の分布が必ずしも一様でないことも考えられるけ れども，これに対する特別の検討は行っていない。この ような不確定要素も含めた平均值が上記の $\beta$ の值である と解釈している.

水槽の前面は透明なアクリル板，後面は鋼製 である が，この鋼製面に水頭測定用の多数のバルブを配してい る. 水頭測定はその変化が急激であるため, バルブより 取り出したビニールパイプを 1 か所に集め（写真一1，2 参照). これらパイプ内の水位変化を連写機能を有する カメラで撮影し, 写真上で読み取り顕微鏡により判読し た. 読み取り精度は $1 \mathrm{~mm}$ である(写真一4). 図一7,8 は測定したバルブの位置を示すもので, 図中の直線は有

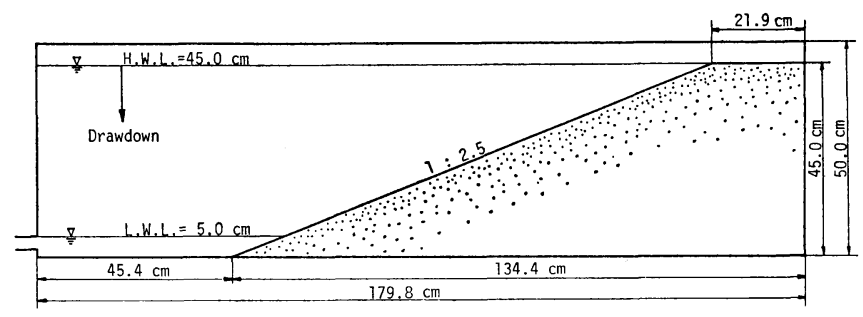

図一5 中央コア型ダムの模型実験

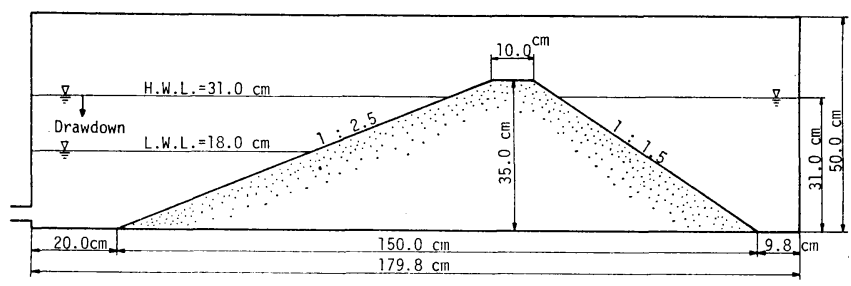

図一6均一型ダムの模型実験
限要素解析に用いられる nodal line を表 わす.

以上とは別に，非ダルシー流れとしての 運動方程式を決定すべく図一9に示す装置 で透水試験を行った.むろん，このときの 試料の詰まり具合は上述のモデルダムのそ れと同じ状態にある. 透水試験結果を図一 10,11 に示した. 図中・印は測定点を表わ す.運動方程式を Forchheimer 則, $I=a v$

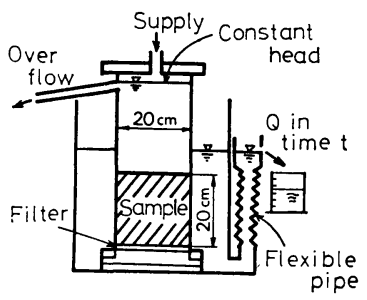

図一9透水試験装粗 


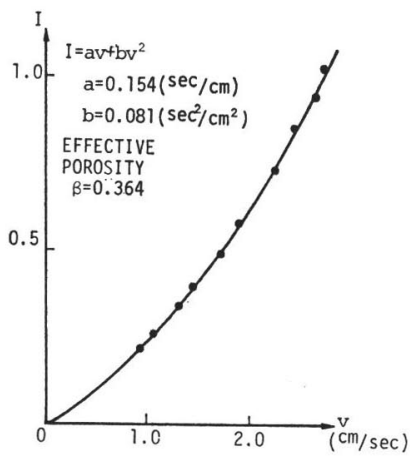

図一10透水試験結果 (中央コア型ダム)

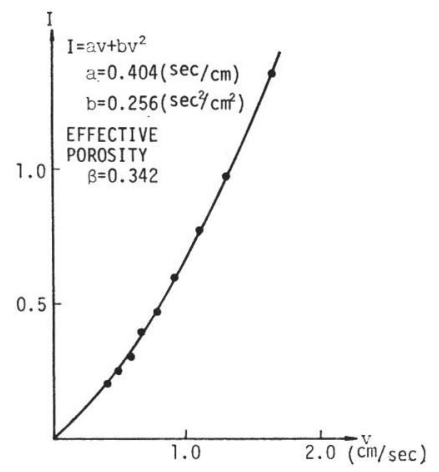

図-11透水試験結果 (均一型ダム)

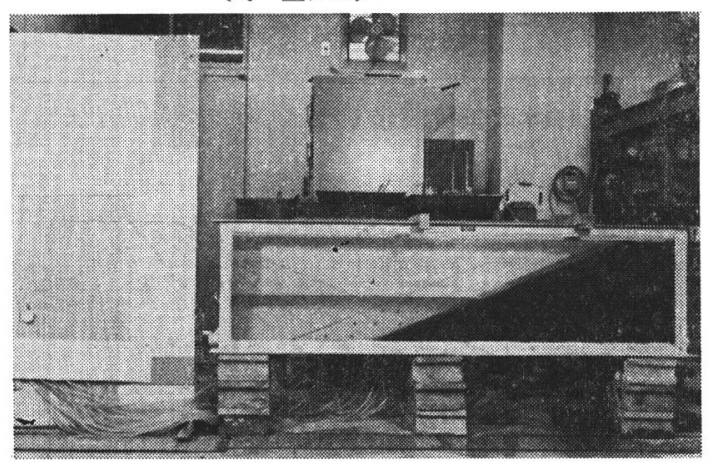

写真一1 中央コア型ダムの全景

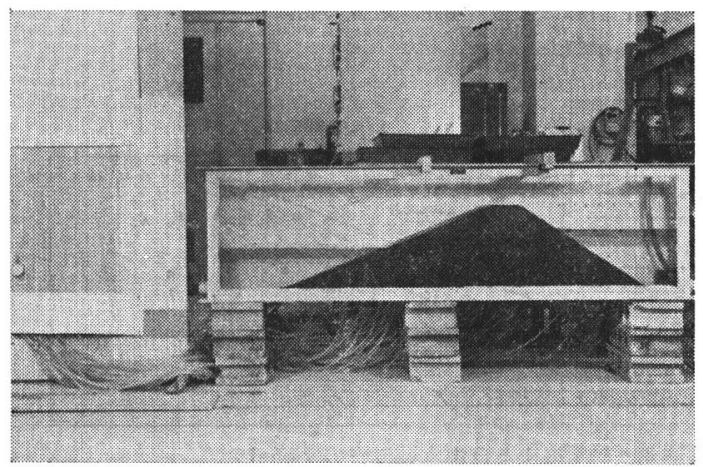

写真一2 均一型ダムの全景

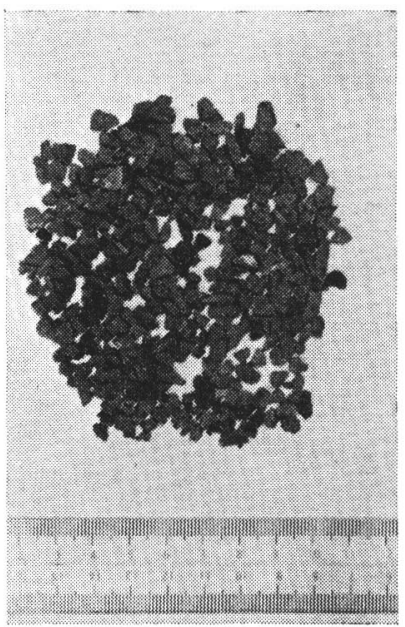

写真一3 ロック材の外観

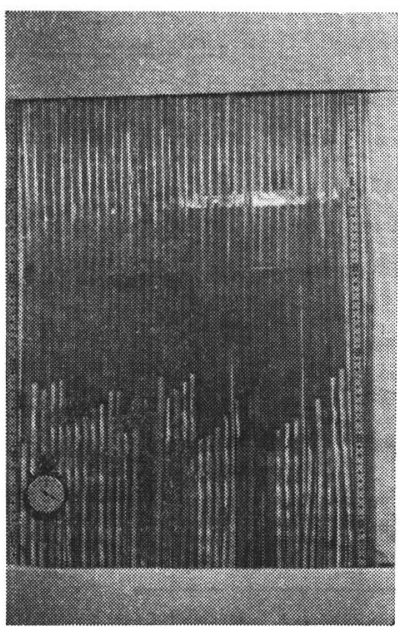

写真一4 ビニールパイプ内の 水頭变化

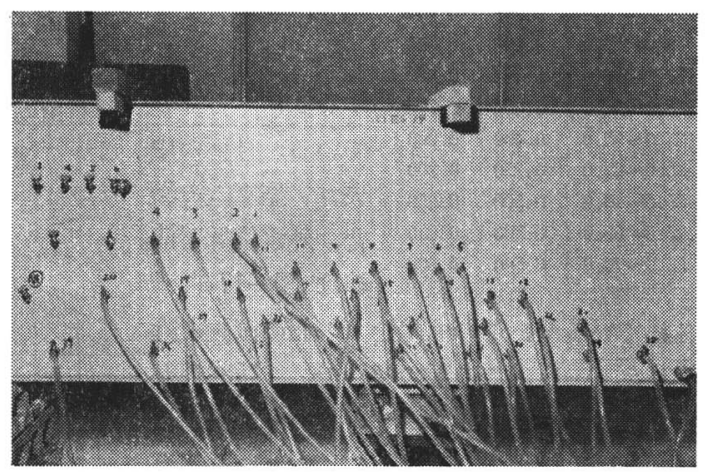

写真一5 バルプの配置状況

$+b v^{2}$, と仮定したとき, これら測定值に最も適合する係 数 $a, b$ を最小自乗法で求めると, 中央コア型ダムに対 し $a=0.154 \mathrm{~s} / \mathrm{cm}, b=0.081 \mathrm{~s}^{2} / \mathrm{cm}^{2}$, 均一型ダムでは $a$ $=0.404 \mathrm{~s} / \mathrm{cm}, b=0.256 \mathrm{~s}^{2} / \mathrm{cm}^{2}$ となる.実線はこのよう な曲線をプロットしたものである。

以上の実験概要を一括して 写真一1〜 5 に呈示した.

\section{4. 解析結果と実測値の比較および考察}

\section{（1） 中央コア型ダムの場合}

図一12 に解析に用いた初期要素分割を示した.この 図の nodal line 上に 図一7 の観測点の多くのものが配 置されているのである. 要素分割図で浸出点近傍に不規 則な分割状況がみられるのは, この解法がダルシー流れ を基底としているため, 先の論文で明らかにした動水勾 配の特異性卢を回避したことによる.

解析に先立って外水位低下曲線を適当な時間の関数で 表示せねばならない.このプログラムでは実測された曲 


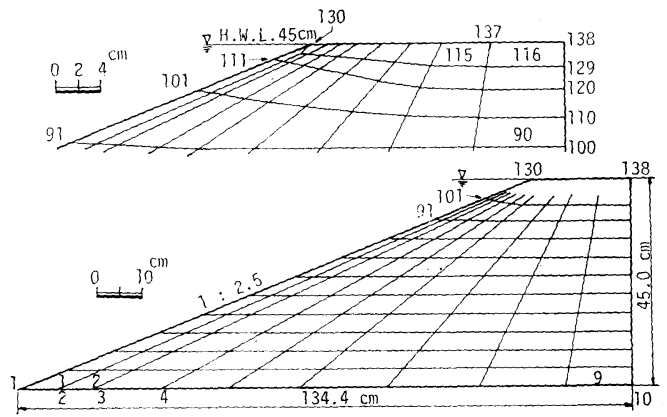

図一12 初期要素分割図 (中央コア型ダム)

表一1 タイムステップ 線を最高 10 個ま の詳細

\begin{tabular}{c|c|c}
\hline $\begin{array}{c}\text { 封間区分 } \\
(s)\end{array}$ & \multicolumn{2}{|c|}{\begin{tabular}{c}
\multicolumn{2}{|c}{ タイステップ } \\
$(\mathrm{s})$
\end{tabular}} \\
\hline $0.0 \sim 2.3$ & $\mathrm{~A}$ & $\mathrm{~B}$ \\
\hline $2.3 \sim 8.0$ & 0.115 & 0.115 \\
$8.0 \sim 14.0$ & 0.305 & 0.190 \\
$14.0 \sim 18.0$ & 0.400 & 0.200 \\
$18.0 \sim 24.0$ & 0.400 & 0.200 \\
$24.0 \sim 30.0$ & 0.400 & 0.200 \\
$30.0 \sim 35.0$ & 0.250 & 0.200 \\
$35.0 \sim 45.0$ & 0.500 & 0.250 \\
$45.0 \sim 55.0$ & 0.500 & 0.250 \\
$55.0 \sim 70.0$ & 0.500 & 0.300 \\
\hline
\end{tabular}
での折線の連なり で近似することに している.そして 各淔線区間内では 等しいタイムステ ップを用いて計算 する仕組みとなっ ている.目下の中 央コア型ダムの場 合，外水位低下曲 線は図一17 に示 されているが，この曲線を 10 個の直線で近 似した。一般にこの種の解析では, 透水性が 大きいとき十分小さなタイムステップを選ば なければ自由水面低下が著しく大となり不合 理な結果を招く。ここでは実際上どの程度の タイムステップで計算すればよいのかを明示 する意味も含め, 表一1 に示すような 2 種類 のタイムステップを用いた解析結果を実験值 と比較し，精度の検証を試みる。表一1に打 いて, 時間区分とは外水位低下曲線を 10 個 の直線で近似したときの各直線区間に対応す る経過時間の範国を表わす.そして各直線区 間内では等間隔のタイムステップが用いられ ており，それらの値が $\mathrm{A}, \mathrm{B}$ 欄に示されてい る、表から明らかなように, 大略 $\mathrm{A}$ は $\mathrm{B} の$ 2 倍の大きさのタイムステップであるといら ことができよう．以下，Aをタイムステップ 粗な場合，Bをタイムステップ密な場合とよ ぶことにする・なお, 運動方程式に関する誤 差の許容值 (EPS と記す) はここに示す解 析例いずれも $\mathrm{EPS}=0.1 \mathrm{~cm} / \mathrm{s}$ である.

まず, 図一13,14 は A, B 2 種類の夕イ ムステップのもとに計算された自由水面の経 時変化をそのときどきの外水位とともに示し
たもので，印は nodal line 上の自由水䤄位置を表わ す。一方，観測による自由水面形状を精度よく決定する ことはここで行ったような小型の模型ダムの場合，わ ずかな毛管水帯の存在が微妙な影響を及ぼし非常に困難 となる、そこで次善の策として図一7の個々のバルブの 位置に注目し, 実測による自由水面（圧力水頭零の面） が各バルブ位置に到達した時刻の計算による自由水面位 置を nodal line 上で比較することにした。このような データをプロットしたのが図一15，16である.図中。 印は実測による自由水面位置（バルブの位置）を，また

・印は同じ時刻における計算による自由水面位置を表わ

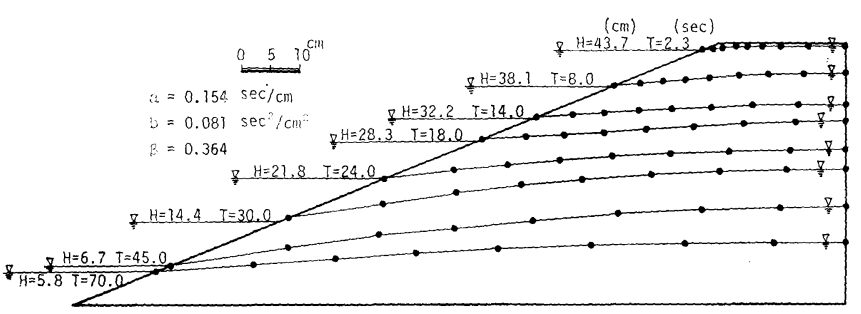

图一13 計算による自由水面の経時変化（タイムステップ粗な場合）

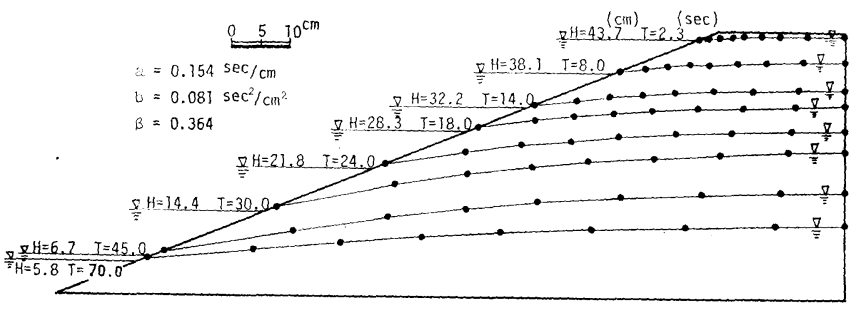

図一14計算による自由水面の経時変化（タイムステップ密な場合）

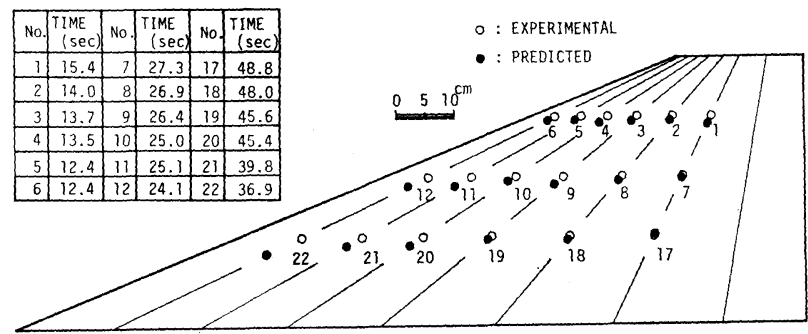

図一15 実測と計算による自由水面位置の比較（タイムステッ プ粗な場合）

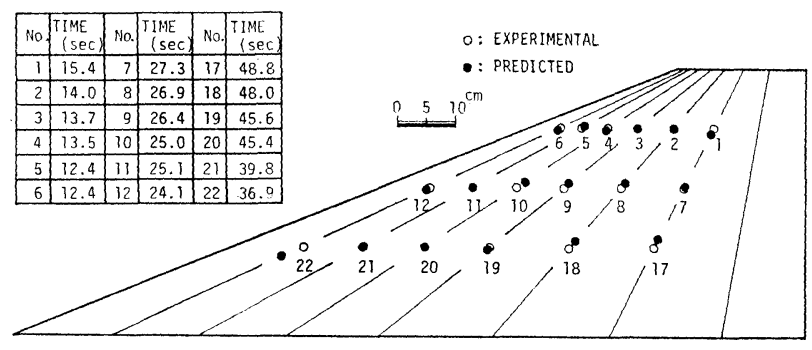

図一16 実測と計算による自由水面位置の比較（タイムステッ プ密な場合) 
す.そしてこれらの自由水面位 置を与える経過時間は一括して 図中の表に掲げた.この表で No. はバルブの番号を, TIME は自由水面がそのバルブ位置に 到達するまでに要した時間(秒) である。

次に, 図一17 は適当なバル ブ位置における水槽底面を基準 面とした全水頭の時間的変化を 外水位とともに示したもので, 実線は実測值，○印および×印 はそれぞれタイムステップが粗 な場合と密な場合の計算值であ る.

はじめにタイムステップの相 違が自由水面変動に及ぼす影響 をみてみると，図一13〜16 か ら明らかなように, タイムステ ップの粗な場合が全体として自 由水面降下速度がいくぶん速く なっていることが認められる.

こうした傾向は非ダルシー流れ に限られたものではなく, 非定 常自由水面解析に共通して経験 される現象である．通常この問

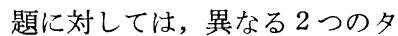
イムステップで計算された結果 がほぼ同じ状態を与えるとき， 正しい解を得たものと解釈して いる.

次に, 数值解と実測值を比較 寸れば 図一15 の自由水面位置 は流出面に近づくにつれ両者の ずれがやや大きくなっているも のの, タイムステップを密にし た 図一16 はこの点がかなり改 善されている.一方, 図一17の 全水頭に関してはタイムステッ
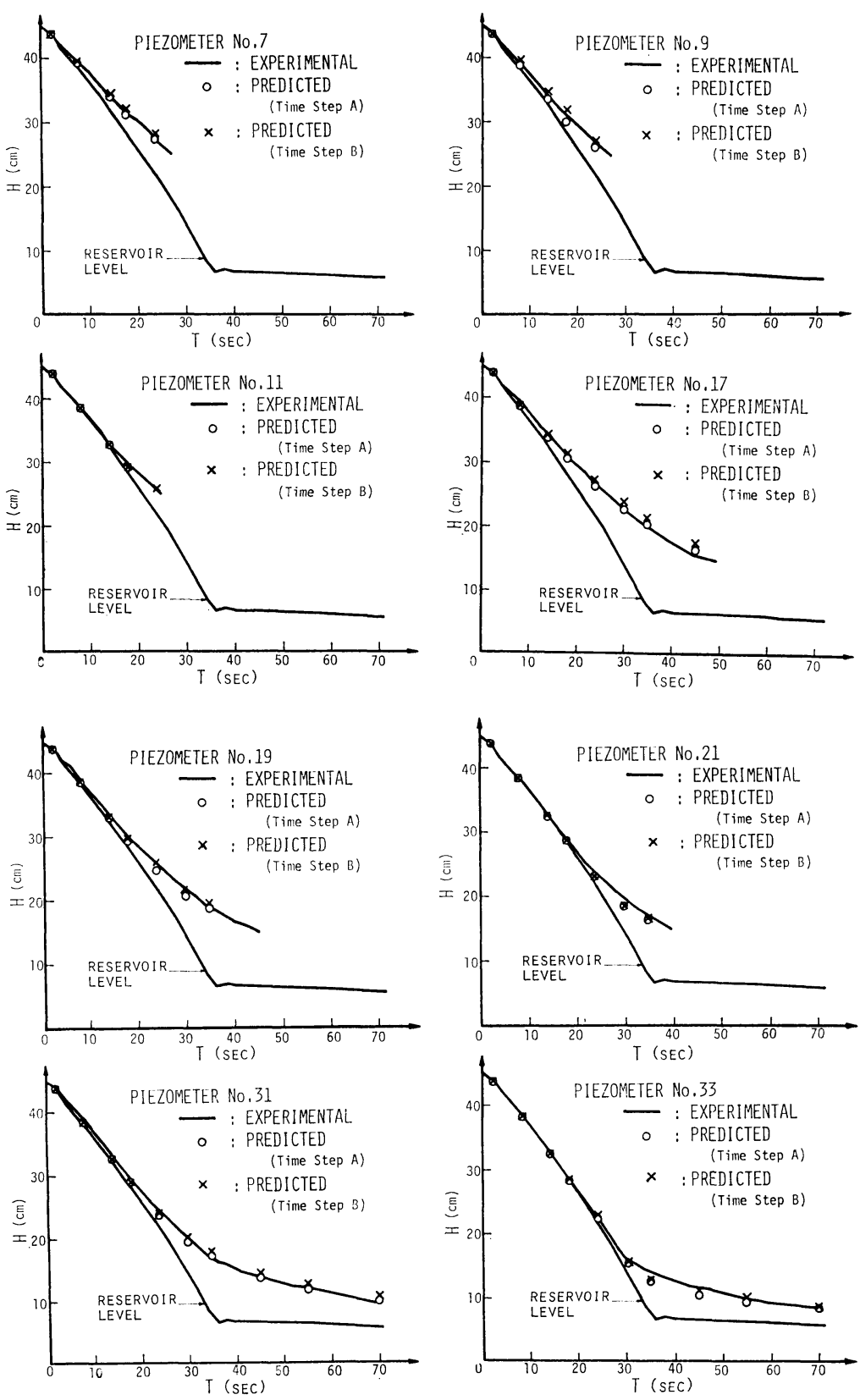

○:タイムステップ粗 $\times:$ タイムステップ密

図一17 バルブ位置における全水頭の比較

プの粗密にかかわらず計算值は実測值と非常によい一致 をみている. 図一17 の一致度に比して図一15 のずれが いくぶん大き過ぎる感がしないでもないが，これは 図 -15 があくまでも傾斜した nodal line 上で比較してい るためである. 仮に実測自由水面の全体像が与えられた として 図一13 にプロットすれば，両者のずれの程度は 図一15 にみられるほど大きくは感じないであろう。

\section{（2）均一型ダムの場合}

先と同様 図一18 に初期要素分制, 表一2 にタイムス テップの詳細，図一19 に計算による自由水面の時間推 移，および 図一20 に全水頭の変化を示した。これらの 図ないし表の意味するところは中央コア型ダムの場合と 同じであり，その説明は省略する．ただし中央コア型ダ ムで得た 図一15 もしくは図一16に相当する実測值と 


\begin{tabular}{|c|c|c|}
\hline \multicolumn{2}{|l|}{ 表一2 } & 解析結果の比較 \\
\hline $\begin{array}{c}\text { 時 間区 分 } \\
\text { (s) }\end{array}$ & $\begin{array}{l}\text { 多1 } \\
\text { スデン } \\
\text { (s) }\end{array}$ & $\begin{array}{l}\text { ない. その理 } \\
\text { は, 図一19に }\end{array}$ \\
\hline $0.0 \sim 2.8$ & 0.140 & 5自由水 \\
\hline $2.8 \sim 4.9$ & 0.420 & \\
\hline $4.9 \sim 25.6$ & 0.517 & \\
\hline $25.6 \sim 55.4$ & 0.596 & 火槽の \\
\hline $55.4 \sim 118.1$ & 0.627 & \\
\hline $118.1 \sim 150.6$ & 0.706 & \\
\hline $150.6 \sim 198.5$ & 0.704 & $+\infty<$ \\
\hline $198.5 \sim 234.0$ & 0.710 & $\varnothing$ \\
\hline
\end{tabular}

る・上・下流側水位差をもら少し大きく とればこのようなデータの整理も可能で あるけれども，その場合は堤体の局部破 壊を招く恐れのあることはすでに記した ところである。

図一20をみれば，均一型ダムの場合 もかなりの精度で実際挙動を近似してい るといってよいであろう。

以上，非常に簡単なモデルではあるけ れども 2 つの模型実験と比較した結果， 少なくとも提案する簡易解析法を否定す べき事象は見当たらない。

ところで，ここに呈示した非ダルシー
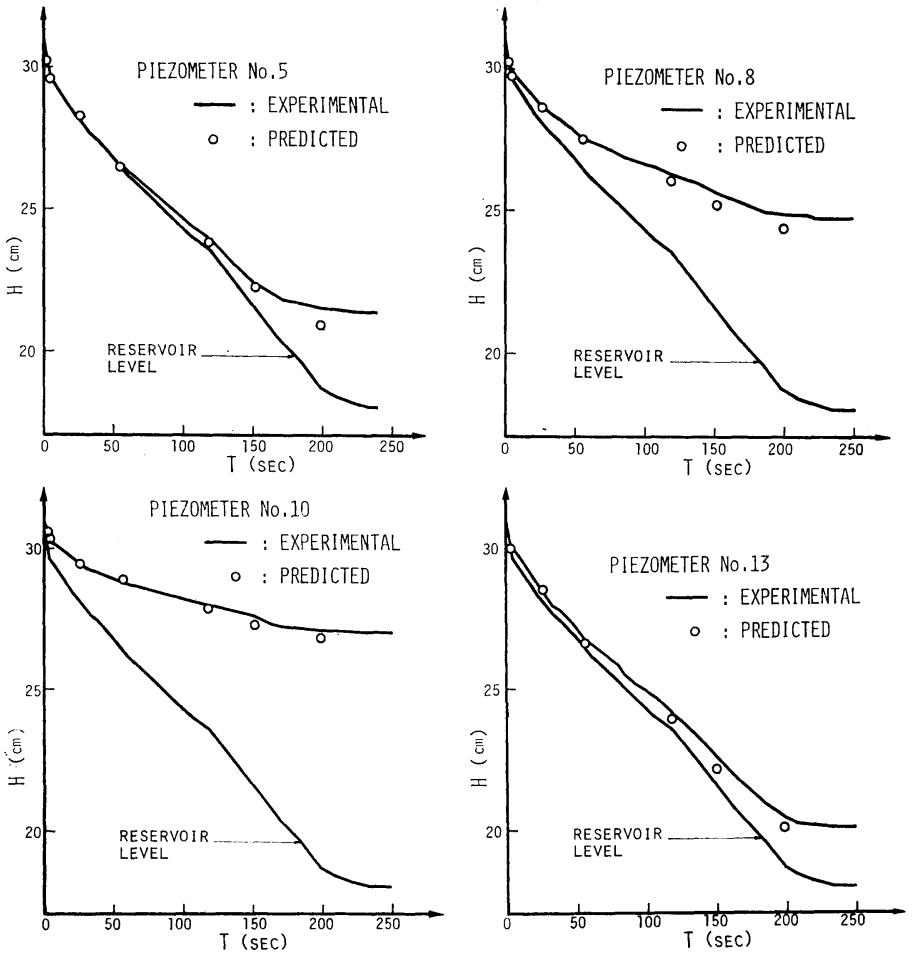

図一20 バルブ位置に
流れとしての解析例に対し, 図一10，11 の実測データ を平均してダルシー流れとして解析すればいかなる結果 を与えるのかといった疑問が当然生じるであろう．仮に ダルシー流れとして解いた結果が十分な精度で実測值を 予測し得たならば，あえて非ダルシー流れの解法をとる
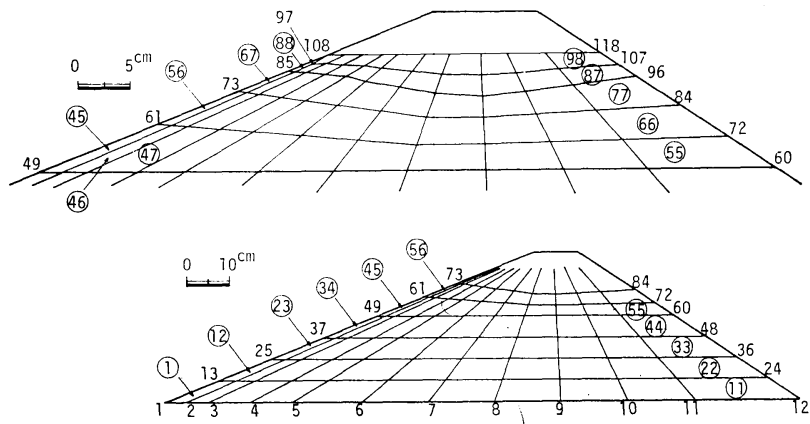

図一18 初期要素分割図 (均一型ダム)

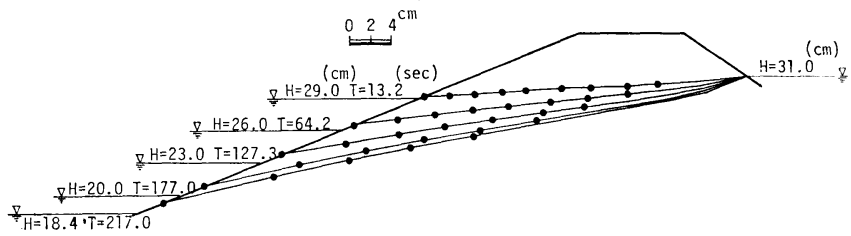

図一19計算による自由水面の経時変化
必然性は存在しないわけである. しかしここでは，以下 に記述する理由により，このようなダルシー流れとして の検討は行っていない.

ダルシー流れとしての検討を試みていない理由を説明 するために，まず解析の全段階を通じていかなる範囲の 割線透水倸数のもとに計算されたのかを明ら かにする必要がある. 図一21, 22 は前記 $2 つ$ の問題に対し，この状況を図示したものであ る. 中央コア型ダムの場合, 割線透水係数の 最大值は $k_{\max }=6.49 \mathrm{~cm} / \mathrm{s}$, 最小値は $k_{\mathrm{min}}$ $=3.24 \mathrm{~cm} / \mathrm{s}$, また均一型ダムでは $k_{\max }=$

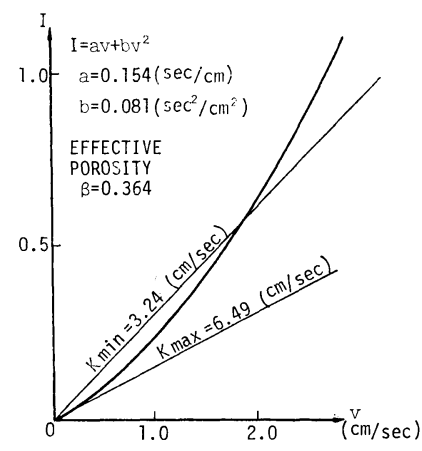

図一21 割線透水係数の変動範囲 （中央コア型ダム） 

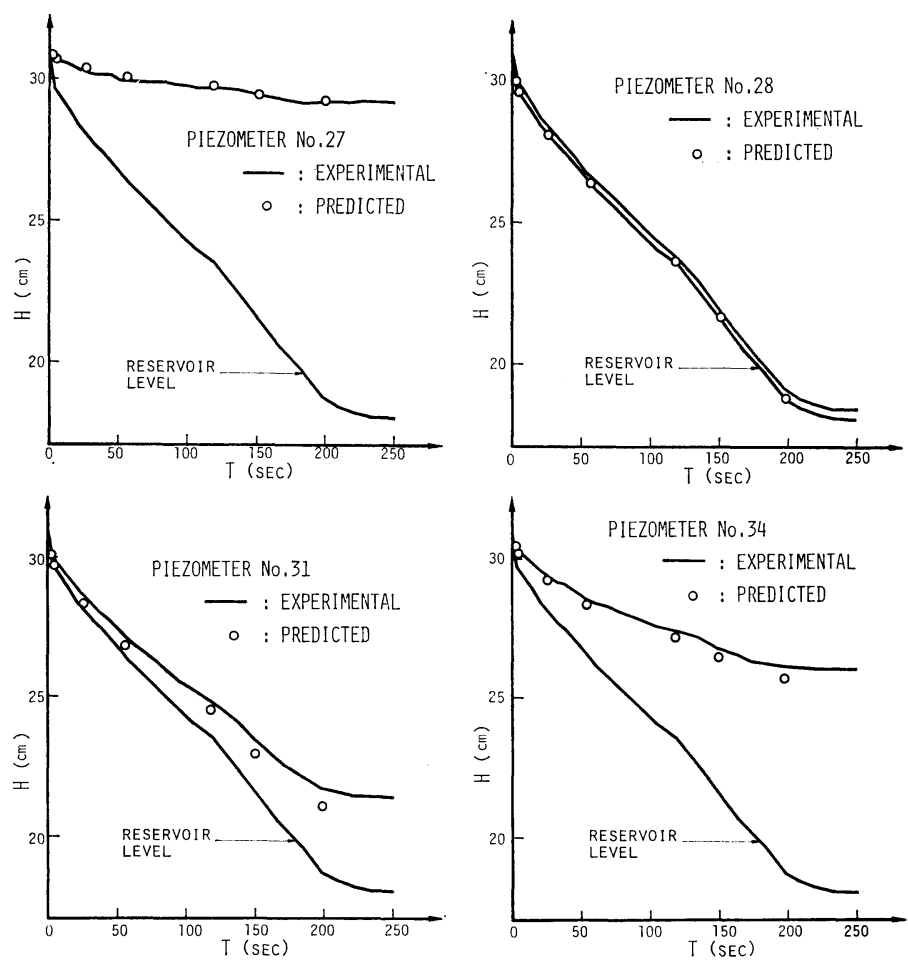

おける全水頭の比較

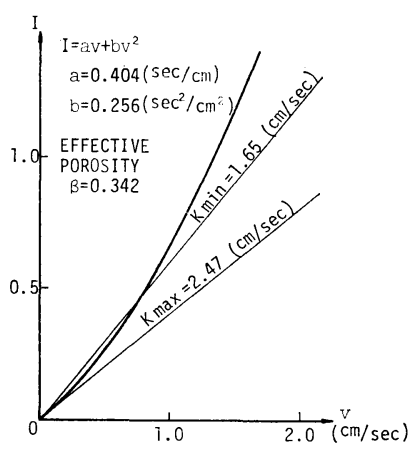

図一22 割線透水係数の変動範囲 (均一型ダム)

$2.47 \mathrm{~cm} / \mathrm{s}, \quad k_{\min }=$ $1.65 \mathrm{~cm} / \mathrm{s}$ であった. ただし，要素網がた えず修正されるため このような透水係数 を与える要素を特定 することはできな い.これらの図から， 中央コア型ダムにつ いては $k_{\max }$ と $k_{\min }$ の平均值 $k_{\text {mean }}=$ $4.87 \mathrm{~cm} / \mathrm{s}$ を,また均 一型ダムでは $k_{\text {mean }}$ $=2.06 \mathrm{~cm} / \mathrm{s}$ あたりを用いてダルシー流れとして解析す るならば，本実験に関する限り，あるいは非常に精度の 高い結果が得られるかもわからない. 特に均一型ダムで は $k_{\max }$ と $k_{\min }$ の值が比較的接近していることから， ダルシー流れとして解いても十分な精度が期待できるで あろう。しかしながら，こうした論理が成り立つのは 図一21 や図一22にみられる割線透水係数の取り得る範 井が前もって与えられたときだけである. 通常, 未知の 問題に対し, 運動方程式上で割線透水係数が変動する範 囲を事前に予測することは非常に困難である。したがっ て適当な平均值を用いて解析すれば, 偶然高い精度の解
を得ることもあ るであろらし, 表一3 演 算 時間 (FACOM M-190)

またそれと同程 度の確率で非常 に大きい誤りを 中央コア型タム $\mid$ 均 一 型 犯す可能性も潜 在するといえよう.

このような危惧があるため，ここでは ダルシー流れとしての検討は行っていな いのである.

次に, 数值解析の立場上いま一つの関 心事である演算時間について簡単に触れ よう. 表一3 は 表一1，2 のタイムステ ップのもとに図一13, 14 および 図一19 で与えられている最終自由水面を求める までに要した演算時間 (CPU Time) を 掲げたもので, 計算機は京都大学大型計 算機センターFACOM M-190 である. ただし，連立方程式の解法はバンドマト リックス法を応用している7).

この表から明らかなように，それほど 多くの演算時間を要することなく解析で きている，演算時間があまり大きくなら ない根拠は, この種の解法が一般にタイムステップをか なり密にとらなければ安定な解を得ることは困難である けれども，この事実が逆に幸いして，タイムステップが 小さければ小さいほど 図一3で説明したタイムステップ 当たりの反復計算回数が減少することによる. 実際, こ こで例示した問題では運動方程式に関する修正回数は多 くのタイムステップで 1 回であった.

以上, 模型実験との比較を総合的に判断すればここの解 析法の妥当性が裏付けされたといえるであろう.

\section{5. 結語}

粗粒材よりなる多孔体中の浸透現象が多くの場合非ダ ルシー流れとなる事実にかんがみ, 運動方程式の非線形 性を線形計算の反復で近似しつつ非定常自由水面を追跡 する簡易解析法を提案した. その概要は定常非ダルシー 自由水面流れで展開した割線透水係数に基づく反復法の 概念と, ダルシー流れとしての自由水面の移動方法を結 合したものである.この方法のほかにみられない特徵を 簡潔に表現すれば, 理論構成がきわめて単純でダルシー 流れの解析と本質的な相違点はなんら存在しないといら 点に尽きるであろう.

本論文で議論した要点ならびに得られた結論を摘記す れば次のようにまとめられる。 
（1）割線透水係数の概念を応用し，各タイムステッ プごとに運動方程式の非線形性を満足するための反復法 の手順を詳細に論述した. 同時に, 飽和領域のみを対象 とした自由水面の移動方法に伴ら難点を指摘するととも にその回避策を検討した.

（2）提案した簡易解析法の精度を検証すべく砕石を ロック材とする 2 種類の模型実験を行った. そのタイプ は中央コア型ロックフィルダムと均一型ダムであり, い ずれも貯水池水位低下時の非定常浸透に伴う圧力水頭の 時間推移を測定したものである.

（3）模型実験と同じ状況を数值解析し, 両者の結果 を自由水面位置および全水頭の面から比較検討した. そ の際, 特に中央コア型ダムと関連してタイムステップの 大きさが解析結果に及ぼす影響を例示した. そしてこれ らの比較から, 流出面近傍で計算による自由水面降下が いくぶん速やかであるけれども，全体としておおむね一 致しており, 提案した解析法の妥当性が確かめられた.

(4) 本文においては一般に多く行われている透水試 験結果を平均化してダルシー流れとして解析することは 試みていないが，その論理的根拠を略述するとともに, 提案した解法が演算時間の面でも十分実用に耐えること を例示した。

以上ここに述べた簡易解析法で非ダルシー流れを考 慮することにより, フィルダム法面の浸透流による安定 性をさらに厳密に検討できるものと考えている．なお， 目下この方法の工学的意義をより高めるため, 飽和・不 飽和領域を一体とした解析法に拡張しつつある旨記して
本文の結びとしたい.

謝辞：筆者の一人（山上）は，本論文のみならず 研究の全般を通じて京都大学教授 赤井浩一先生にご指 導賜わっている.ここに記して厚く御礼申し上げます.

\section{参 考 文 献}

1）川上拓男・小田英一：有限要素法による非ダルシー浸透 流の一解法, 土木学会論文報告集, 第 234 号, pp. 111 120,1975 .

2) McCorquodale, J.A. : Variational Approach to NonDarcy Flow, Proc. ASCE., Vol. 96, HY 11, pp. 2265 $\sim 2278,1970$.

3) McCorquodale, J.A. and M.S. Nasser : Numerical Methods for Unsteady Non-Darcy Flow, Finite Element Methods in Flow Problems (ed. by J.T. Oden, O.C. Zienkiewicz, R.H. Gallagher and C. Taylor), UAH Press, The Univ. of Alabama in Huntsville, pp. $545 \sim 557,1974$.

4) Huyakorn, P.S. : Finite Element Solutions of Transient, Tow-Regime Flow towards Wells, Proc. of the 1974 Int. Conf. on FEM. in Eng. (held at the Univ. of New South Wales), pp. 799 813, 1974.

5）山上拓男：有限要素法による非定常浸透流解析に関する 一考察, 七木学会論文報告集, 第 263 号, pp. 85 95, 1977.

6）赫井浩一大西有三・西坦 誠 : 有限要素法による飽和一 不飽和漫透流の解析, 土木学侌論文報告集, 第 264 学, pp. 87 96, 1977.

7） C.S. デサイ, J.F. アーベル（山本善之訳）：マトリック 不有限要素法, 科学技術出版社, pp. $19 \sim 22$, pp. $497 \sim$ 527,1974 .

(1980.3.17 ·受付) 